\title{
Identity Alienation in Literature
}

\author{
Prof.ass.dr. Elvira Lumi
}

\author{
Msc. Lediona Lumi \\ "A.Xhuvani" Universitety, Elbasan, Albania \\ Email: elviralumi@yahoo.com/ lediona12@yahoo.com
}

\section{Doi:10.5901/ajis.2015.v4n1s1p53}

\begin{abstract}
Alienation is a familiar theme in the prose of Ismail Kadare and Kuteli Mitrush. This theme is defined as an emotional isolation or detachment from others, a way of thinking in exile. In the works of Kuteli and Kadare, the characters are continually alienated and they experience isolation from the society. These characters are physically and psychologically separated from their loved ones. The tough conditions of the society are the causes of their isolation. The characters want to hide their identity from a kind of punishment or guilt that can judge or condemn their conscience. The characters' archetypes appear phantasmagoric, hallucinated and in hypnosis. They are mutilated and demoniac. Alienation stems from a state of despair, disruption of connectivity, a search for escape from the path of death. For Kuteli the weather has changed, the country has changed, the people, their names and clothes have changed. Everything has become strange and the writer feels "a stranger among strangers", "dead among the living". This alienation has not affected the man's skin, which has remained the same, but something essential has been changed. His soul, as the core of the body, has migrated feeling better in exile, far from the ordinary life, he feels a stranger in a metamorphosis reality. The equilibrium between the substance that has been alienated and the form that has remained empty, almost barren, looking for the necessary rediscovery of a new identity carried by the human being.
\end{abstract}

\section{Introduction}

In Mitrush Kuteli, the literary text intrenches with the music, to produce the higher scale of communication. Figuration and linguistic stylitization is in function of the expression form and poetic logic, which contrasts the deformation and transfiguration of human characters. The characters remain beautiful and perfect even after they are dead. In the story of "Rine-Katerineza", Rina's mother from the grave, through the phenomena of Metamorphosis, resurrects and sings: "Don't cry, my child, Mos më qaj, moj bijëzë, Rinë -Katerinëzë, or you'll ruin your eyes, Se të prishen syzetë, or you'll ruin your cheeks...Se të treten faqetë... When the dead spoke like this, it was almost nightfall and the wind blew on grass and thorns.

Such pray we find even in the figure of Petro, who though murdered, prays:

"You vultures which fly around, Yve gala që vërtiti, Eat whatever you want, Të më hani ç'të më hani, Just spare me the eyes, Sytë e mia mos m'i ngani, No one want an ugly son...!Se jam djal' e më shëmtoni ... 1

In stories with fantastic subjects the author offeres the relationship of the living with the dead, their liason, as in the stories: "April Night", "Night of May" "Rine-Katerineza", "June Night" "The Letters of Nightfall", "Mutiny for devil". In every relationship of the living hero with the dead a comeback of this hero in the living world is predicted, but he is changed and transformed as he himself affirms "a stranger between strangers"2 Kuteli together with Kadare, is presented as one of the most interesting prosators of the Albanian literature. The art of Kuteli is supported by a classic narrative architecture as much as a modern tradition like short stories as a literary genre, which this author develops. The classic narrating form according to the spoken tradition intreches with original models as the phylosofical discourse and as the approaches of the narrative author on the universal problems of existence, life, death, right and even priciples like those of "relativity".

${ }^{1}$ Kuteli, M. "April Night" from "Kapllan Aga of Shaban Shpates"

2 Kuteli, M."Rinë-Katerinëza", "Chosen prose and lyrics, 2", Tiranë, 2004. 
The narratives of Kuteli surge above all from his reflections and the ability to create an architectonic text, which with the masterfulness of a manufacturer presents "partly symbols, partly scenes of an idealizing reality" with a creative breath, the sunset and destroyal of a life which is exchanged "almost normally with death". These relationships are fourdimensional and relate to the organic and mathematical building of life and death. In the prose of Kuteli is presented the idea of "divine singers" and the "leader of the harmony spirit in the world", where the architectural text and music originate. ${ }^{3}$ Through allegories and symbols the author has adapted it the typology of the "living dead" which is played in the 7- syllable lines a divine fantasy (refer to the above lines for this). The content of Kuteli prose belongs to a pitagrorichal esthetic proportion, where the fantasy which takes the same from the musical prototype of the architecture, the ideas of a reality, is identified with a building which remains beautiful forever. This is what the author writes: "...step by step like from the present Being started to raise a sort of finely veil woven from the waves of time. This resembled a caddis that edged and faded away in the dusk. Then, the waves of land and grasslands, forged in walls and stones, drew appart like with an order, and in a blink of an eye, all the ancient buildngs grew from the ground, each in its place. Now Katjeli, this pleasant village of Mister Nikoll Branës, appeared to my eyes the same as it was four or five generations before"4

Only if you see the object, the phenomena or poetic figure in the inside you can discover beauty. It directs you 'to see the novelty with the eyes of the mind". This novelty is given to us through the act of construction and the structure of this construction with elements like stile, wall, house, village, etc.

In the fantasy of "Kuteli the architect" his devotion, courage and "destiny" and "enumerating" gift and formation to that scale where at last, in the highest row is found the guarantied success of the narration, glory and perfectness which coronate the narrator-architect himself, are an integral part of him.

The mythical prototype and honoring the artist in the present, coronate two cycles which transmit to the reader a free esthetic education. The language of the narrator is presented in a symmetrical approach of the picture, plastic and architecture. The prose "My village drinks raki" is an example where Kuteli is presented as a "genius of sculpture", who can create in accordance with the burning torches of life, the bitter prints of a treasure which is nothing but coal used everywhere, the prints of which identify the author himself with his never ending energies in service of literature and narrative prose. As a "practical construction servant", Kuteli is capable with his "landscape symbolic" and revivance metaphoric to extract with this architecture the future of his modern building with stones and tiles and the amazing relation of the "gothic" vertical constructor and the "greek" horizontal division, by aiming to present the decoration of the narration building, the necessity of a mental synthesis like the esthetic prototype of the poetic figure, as the tropes and her obligation of education.

Life and death are presented in the same plan, where the line of genesis moves in the form of an oval or parabolic curve, which are repeated as a primary type of genesis with ever changing powers. This way of judging puts the authornarrator in a viewpoint of life according to the principle of organic metamorphosis and the geometrical method of discovery. Kuteli in this case is a prospective author. The poetic language of his narration resembles an iconographic symbolic, which aims to fix not only the internal communication signs as discourse, which maybe are related to his personal tastes or personal life; but to give these signs as secrets of church icones, early historic documentations until the anxiety of discovering treasures or everything old related to very rare stones which seem to be in search of the Illyrian genesis. Although he is an admirer, Kuteli is against the customary imitation of nature. In this case a crucial role plays the imagination and fantasy, knowing the historical and legendary myths and fantastic narrations of the childhood.

Nevertheless, his narrations are not bedtime stories, but catalizators of the historic memory of the nation itself. Kuteli tries to approach as an artist to the "prototype" and "original nature" and to gain from them "the necessary idea on beauty". The world of minerals (copper, gold, silver which are related to the activity of the sun on earth), of animals and plants, is used from the artist "but only as subordinated clauses" of a narration and "never with over-measures or either for an idea set on reason which aims to disclose beauty itself".

In stories like "Albanian nights" we discover a series of elements which have been taken from reality in nature. These physical elements compose the almost sacred human spirit of men and his eternal concern on the possibility of embodiment and resurrection. The short prose of Kuteli unites the units and components of the trait of the being that carries in it "the genuine or the evil spirit"s. In this spirit we find "the personal understandings" of the writer as "a path of

\footnotetext{
${ }^{3}$ Lichtenstern, Ch., "Die ëirkungsgeschichte der Metamorphosenlehre Goethes",

${ }^{4}$ Kuteli, M. "August Night" from "Beyond the waves of times" of "Chosen prose and lyrics", see above

${ }^{5}$ Kadare, I. "Only skin has remained to the bond", Newspaper"Metropol", 18 February 2005
} 
life 6 in search of the lost truth". This truth is discovered if simple transformations are overpassed and through the principle of Metamorphosis the concept of growth as a progression is disclosed (see the fragment above), of degradation ("The Autum of Xheladin Bey"), of resurrection ("The Letters of nightfall", "The devils of our village").

As it happens with oral narrations, in Kuteli we often find chlishes that open or close his short prose. These chlishes enable the reader to receive in an uninterrupted way, component elements of the genesis like water, fire, bread, air, light, sun, and moon, minerals (which serve for monetary value, like dishes or decorations tools).

A group in itself consist the construction elements and architectonic structure of historical or cult objects like: the grave stone, cave, stairs, castle, village, town, colones, churches, mosques until their transformation in coal or carbon, which compound the first matter for a classic writer like Kuteli. These are the elements we can find in a visible way in the prose of Kuteli, which direct this author towards anthropology and collective claims for change. This concept is related with the fundamental Christian thought of transsubidition as a central impuls of creation, especially those related with the topic of Metamorphosis. Metamorphosis, transsubsidition are often treated by Kuteli and probe and affirm him as "an artist with catholic education, with an early interes in oral narration, mathematics, the penetration of his concept on art not only as a "mimes", but also with a breath of human resurrection, principles which conform closely with the theory of "Metamorphosis of Gëte plants" or his "Morphology" and "Qualified Gëteism" of Rudolf Shtainer.

Metamorphosis is a crucial principle which organizes the narration of this author through which he discloses the human not only as a being with known form and content, but also as a shadow without content and stripped from its soul. Emerges the question: what has concerned this writer, only the relationship life-death, or any personal secret, like the well-known researcher A, Plasari suggests?7

Kuteli leaves the common reality to find peace in a narration structure of characters in exile. This narration requires a certain logical order and an endless continuity of metaphors by trespassing the simple transformations and comparisons of men with boggards, with angels, and by touching the darkes and deepest corners of the human soul. The particular layers of the narration symbolic, a palimpsesty language, is discloses as a principle of Metamorphosis, that we find in the stories "Beyond the waves of time", "The second revelation of Pjetër Kulirës", "Albanian Nights".

Creativity and the "social plastic" that entrenches the prose of Kuteli and Kadare raises above a child psychology that brings into memory grandparents or parents the tales, of childhood or early youth, but that are put in form of revelations above each other as a property of selfconfience of the narrative author. The main theme of narrations is that of self-formation and creation of the human identity in a social reality often very extreme and astrange with this individuality that is formed in the almost absurd conditions of the struggle to survive. The architypes of the characters are presented as fantasmagoric, halutinants and under hypnosis. Borroved and truncated persona are disclosed in a totalitarian society and they discover the exile of the characters. By being modern on the way of understanding life our authors rise above a certain line of tradition, by disclosing their prose not only a very secret logical element but also an esthetic element and at last a religious element.

The writer narrates for "a new life", where people would eat "with a silver spoon" ( why the question of gold torments so much this writer; though we know that he has worked for a short time in the Romanian and Albanian bank as a accountant, during the war and after it). The nature of the characters are presented as an exotic "figure", that unveils different views, often contradictory to the point of deforming the human appearance. This is a demonizated view. The principle of magic that the author uses to organize the structure of classic fantastic narrations like the tropes according to the principle of "reverse" reflection or mirror principle, to understand all that complexity of element of the human soul, to which the author pledges to study the "anatomy'. The spirit of searching and discovering what inspires the author reminds you of the novels of Zh.Vern, which seek to discover the world and the relationship that men have with it. In the narrations of Kuteli one lives in a macro and micro-cosmic world, and through the compontes of plants, animals he reviews analogies with soul-like qualities still unknown to the modern world. These parts represent important elements of the structure of life on earth and through a cyclic exchange of powers from earth and the cosmos is projected the life of the living and non-living nature in our planet. In ratio with life, death is presented by the author as a temporary interruption to reinvigorate the bridge of a new life, that is symbolized with the seasons and months of the year and even with the hours of day and night: "The Letters of nightfall", "Night of May", "Night of August" etc,. Kuteli unveils as a modern and extremely innovator artist. Through his narrations the Metamorphisis is disclosed as an effective principle not only in the organic nature and time, but it is also reconginized as such with its truthfulness and necessity. In addition, this principle

\footnotetext{
${ }^{6}$ Bond Stephenson, D. "Living myth", London, 1993

7 Plastari, A. "The second identity of M.Kutelit", Newspaper "Drita", 3 February 1991.
} 
results as primar even in the narrative structure of I.Kadaresë and K.Trebeshinës, where the analogies and particularities are visible. The mythical events and fantastic tales with a return in a made-up action are now understandable through the transfiguring force of the story. The ancient oral and religious tradition and the continuant search of the author on nature and men are merged in one in Kuteli. The vision of Kuteli offers a type of cyclic circle of events, but also an evolutive kind of imagination and universal ideas. When the events are described according to an cyclic principle, the author is very near the mythical and fantastic description of events (but also to the religious one), when he bravely enters in the depths of the form of constructing the nature of life on earth it offers us the social form of the human being and its evolutive character. Kuteli states with the tongue of his characters that he is "a stranger between strangers" by offering us the universal concept of the metamorphisis of the human soul. Nevertheless, this universality is not explained just in the model of oral narration of its prose. We beieleve that he must have been familiar with the necessary literature on the life and deeds of Ovid, who passed a part of his life as an interned oman citizen in the lands of Romania in the time of the roman emperor August and may have served as an extra incitement for Kuteli in writing his short stories. In the kutelian narrations, nature is preserved in view as a whole and through the phenomena of resurrection/embodiment, but in the form of an animal or a ghost, the transformation expresses the prototype claimed unity "the first men", "the first plant" (according to the idea of Gëte), "the first animal", which is presented in the mobile category of polarity of growth and simultanouesly, time-place relationships are disclosed. In this double real and unreal relationship we discover a special way of thinking and viewing "the first revelation through eyes" and the visive ability of knowledge. The narration takes the appearance of a movable photography or a fim which is read through writing. Kuteli presents a different form of the human soul separated in two genders male-female and discoveres in the same time the cause and consequence. To Kuteli the weather has changed, the place has changed; the people and their names and clothes have changed. Everything has become astrange and he feels as "a stranger between strangers", "dead between the livings" and vice versa. This borrowing has not only touched the skin of men, which has remined the same, but something fundamental has changed. His soul, as a content of this body, has migrated by feeling good in exile, away from the ordinary and completele astrange that surrounds the hero of the tales. The balance between the borrowed content and the hollow form, almost sterile, in search of the necessary reconnection to a new core of the human being, has been wrecked. We beright Martin Camaj when he asserted that Kuteli "is still undiscovered'; we have much to learn by this noteworthy writer.

\section{References}

Kuteli, M ."April Night" from "Kapllan Aga of Shaban Shpates", "Chosen prose and lyrics, 2", Tiranë, 2004.

Kuteli, M."Rinë-Katerinëza", "Chosen prose and lyrics, 2", Tiranë, 2004.

Lichtenstern, Ch., "Die Wirkungsgeschichte der Metamorphosenlehre Goethes", Bon,2002

Kuteli, M. "August Night" from "Beyond the waves of times" of "Chosen prose and lyrics", "Chosen prose and lyrics, 2", Tiranë, 2004.

Kadare, I. "Only skin has remained to the bond", Newspaper"Metropol", 18 February 2005.

Bond Stephenson, D. "Living myth", London, 1993.

Plastari, A. "The second identity of M.Kutelit", Newspaper "Drita", 3 February 1991. 